\title{
Foliar application of humic liquid extract from vermicompost improves garlic (Allium sativum L.) production and fruit quality
}

\author{
D. M. Balmori ${ }^{1}$. C. Y. A. Domínguez ${ }^{1}$ · C. R. Carreras ${ }^{1}$ · S. M. Rebatos ${ }^{1}$ - L. B. P. Farías ${ }^{1}$ · F. G. Izquierdo ${ }^{1}$. \\ R. L. L. Berbara ${ }^{2} \cdot$ Andrés Calderín García $^{2}$ (-)
}

Received: 23 August 2018 / Accepted: 9 June 2019 / Published online: 17 June 2019

(c) The Author(s) 2019

\begin{abstract}
Purpose The beneficial effects of liquid humus applied to plants are well reported in the literature; however, studies of liquid humic application in the production and quality of garlic culture are practically nonexistent. The objective of this work was to evaluate the effects of foliar application of a liquid humic extract from vermicompost (HEVC) that is well characterized by solid-state ${ }^{13} \mathrm{C}$ NMR on garlic production and fruit quality under field conditions.

Methods After 45 days in the field, garlic plants received foliar applications of HEVC at three different dilutions: 1:40, 1:60 and 1:80 (v:v). Humic substances (HS) in HEVC were characterized by ${ }^{13} \mathrm{C}$ NMR CP/MAS spectroscopy. At 125 days after planting, the plants were collected, and growth and production parameters were determined: quantity of garlic cloves, fresh and dry bulb, diameter of garlic cloves and bulb, as well as parameters of fruit quality including caliber, firmness, acidity, brix, pungency, carbohydrate and protein contents.

Results The structure of HS in HEVC is composed mainly of carbohydrates and peptides as well as lignin fragments, explaining the stimulus effects on plant metabolism. The foliar application of HEVC improves the productive, commercial and internal quality parameters of fruits when compared to the control treatment. The HEVC foliar application in 1:40 v:v ratio was the most promising treatment in terms of increases in fruit quality indices, promoting improvements in bulb caliber, numbers of garlic cloves and internal fruit content.

Conclusion The foliar application of HEVC benefits garlic production and fruit quality. The use of HEVC can be a sustainable alternative within the small-scale garlic phytotechnology package.
\end{abstract}

Keywords Humic substances $\cdot$ Biostimulant $\cdot$ Pungency $\cdot$ Garlic

\section{Introduction}

Healthy and environmentally friendly plant-based food production is a priority for researchers and academicians. Organic agriculture presents itself as an efficient alternative and although there are concerns about yield, more recent studies show that well-managed organic production can not only achieve yields similar to those produced

Andrés Calderín García

calderin.andres@hotmail.com

1 Department of Chemistry, Institute of Agronomy, Agrarian University of Havana (UNAH), Autopista Nacional km 231/2, San José de Las Lajas, Mayabeque, Cuba

2 Department of Soil, Instituto de Agronomy, Federal and Rural University of Rio de Janeiro (UFRRJ), BR $465 \mathrm{~km}$ 7, CEP 23890-000 Seropédica, RJ, Brazil by conventional agriculture but also control diseases and pests (Badgley et al. 2007; Crowder et al. 2010; Reganold and Wachter 2016).

One of the most common practices in organic agriculture is the use of composted materials. These materials generate liquid humic extracts that are mostly composed of humic substances (HS), proteins, carbohydrates, amino acids and different macro- and micronutrients. Liquid humic extracts can be obtained from vermicompost produced from bovine manure, chicken litter, urban waste, sewage sludge and other natural and renewable sources (Warman and Anglopez 2010).

The foliar application of these humic extracts in plants of alimentary interest has been shown to considerably increase their development and fruit production. These biostimulating effects can be attributed to the presence of HS that contains humic acid (HA) and fulvic acid (FA) molecules (Canellas 
and Olivares 2014; Canellas et al. 2015). The HS has a supramolecular structural organization composed of chemical domains that allows root-level interaction with plants and exerts stress protection effects (García et al. 2012), which increases the efficiency of nutrient uptake (Garcia-Mina et al. 2004) and stimulates growth through hormonal regulation (Mora et al. 2010).

Foliar application of humic extracts has been shown to increase yield of maize crops, by both increases in quantity and size of the fruits (García et al. 2016a, b). In lettuce crops, foliar application of liquid humus increased leaf area, amount of total proteins as well as the growth and overall development of plants (Hernández et al. 2015a, b). Specifically, liquid humus obtained from vermicompost of cattle manure has been shown to stimulate agricultural yield in crops such as cucumber, rice and broccoli (García et al. 2013, 2014).

Some crops have great importance to countries and regions. For example, garlic (Allium sativum L.) is highly consumed globally, leading to high demand in countries with a moderate climate (Uzo and Currah 2018). Thus, while fertilizer consumption is high in these countries, intensive soil management is needed as yields often do not exceed $3 \mathrm{tha}^{-1}$ (Izquierdo and Gómez 2012).

With this scenario, it is necessary to search for ecologically sustainable alternatives that increase both the amount of garlic production and quality of the fruit. Since these alternatives are not clearly reported in the literature at present, it is difficult to introduce liquid humus into a plant breeding package for garlic production. Taking these elements into consideration, this study aimed to evaluate the effects of humic liquid extract (liquid humus) that is well characterized by solid-state ${ }^{13} \mathrm{C}$ NMR and obtained from vermicompost of cattle manure on the production and quality of garlic crops via foliar application at different dilutions.

\section{Materials and methods}

\section{Experimental area and sowing conditions}

The experiments were carried out on the farm "Conformidad", located in the municipality of Alquizar in Artemisa, Cuba, during October 2017 and February 2018, which is planting season. Planting was performed manually, where previously selected garlic seeds were placed at an approximate depth of $3.0 \mathrm{~cm}$ in simple beds constructed at a distance of $1 \mathrm{~m}$ between the beds. Each bed was prepared with two rows of garlic seeds at a distance of $20.0 \mathrm{~cm}$ between the rows and approximately $10.0 \mathrm{~cm}$ between the seeds (Fig. 1).

The experimental design followed the assumptions of the Latin square design. The soil of experimental area is classified as typical Red Ferralitic according to the Cuban classification (Hernández et al. 2015b) and had the following characteristics: $\mathrm{Ca}^{2+}\left(11.53 \mathrm{cmol} \mathrm{kg}{ }^{-1}\right), \mathrm{Mg}^{2+}$ $\left(3.60 \mathrm{cmol} \mathrm{kg}^{-1}\right), \mathrm{Na}^{+}\left(0.05 \mathrm{cmol} \mathrm{kg}^{-1}\right)$ and $\mathrm{K}^{+}(0.62$ $\left.\mathrm{cmol} \mathrm{kg}^{-1}\right) ; \mathrm{pH}=7.20 ; \mathrm{OM}=3.87 \%$ and $\mathrm{P}_{\text {Available }}=29.7 \mathrm{mg}$ $\mathrm{P}_{2} \mathrm{O}_{5} / 100$ g.

Foliar application of liquid humic extract (HEVC) was performed 45 days after plantation through the application directly onto the leaves when the plants' sixth true leaf had already emerged. Three different dilutions-1:40, 1:60 and 1:80 (v:v)—of HEVC were applied in addition to the control treatment without HEVC application (García et al. 2014). A manual sprinkler was used for foliar application.

\section{Obtaining and characterization of liquid humic extract from vermicompost (HEVC)}

The HEVC was obtained by extracting a basic medium of HS from the vermicompost of cattle manure. A mixture of $\left(\mathrm{NH}_{2}\right)_{2} \mathrm{CO} / \mathrm{KOH} / \mathrm{KH}_{2} \mathrm{PO}_{4}$ with 1:10 (w:v) ratio was added to the vermicompost and stirred for $4 \mathrm{~h}$. Subsequently, the suspension was centrifuged, and the liquid phase was filtered and stored for further application. The HEVC had the following characteristics: $\mathrm{HA}=12.02 \mathrm{mg} \mathrm{kg}^{-1}$, $\mathrm{FA}=13.54 \mathrm{mg} \mathrm{kg}^{-1}, \mathrm{OC}=52.4 \mathrm{mg} \mathrm{kg}^{-1}, \mathrm{Na}=2.4 \mathrm{mg} \mathrm{kg}^{-1}$, $\mathrm{K}=38.33 \mathrm{mg} \mathrm{kg}^{-1}, \mathrm{EC}=9.46 \mathrm{mS} \mathrm{cm}^{-1}$ and $\mathrm{pH}=7.30$.

Structural characteristics of HS compounding the HEVC were determined spectroscopically using the magnetic resonance technique of carbon-13 with cross-polarization and rotation of magic angle $\left({ }^{13} \mathrm{C}-\mathrm{CP} / \mathrm{MAS}-\mathrm{NMR}\right)$. For this, a quantity of HEVC was lyophilized and subsequently analyzed on a Bruker AVANCE II NMR spectrometer equipped with $400 \mathrm{MHz}$ and a 4-mm Narrow MAS probe at 100.163 MHz. The spectra were performed in triplicate with regions of peak signaling and relative quantification divided as follows: alkyl C $\left(\mathrm{C}_{\mathrm{Alkyl}}-\mathrm{H}, \mathrm{R}\right)$ at $0-45 \mathrm{ppm}$, methoxyl and $\mathrm{N}$-alkyl C $\left(\mathrm{C}_{\mathrm{Alkyl}}-\mathrm{O}, \mathrm{N}\right)$ at $45-60 \mathrm{ppm}, \mathrm{O}$-alkyl C $\left(\mathrm{C}_{\mathrm{Alkyl}}-\mathrm{O}\right)$ at 60-90 ppm, $\mathrm{C}_{\mathrm{Alkyl}}-\mathrm{di}-\mathrm{O}$ (anomeric) at $90-110 \mathrm{ppm}$, aromatic $\mathrm{C}\left(\mathrm{C}_{\text {Aromatic }}-\mathrm{H}, \mathrm{R}\right)$ at $110-140 \mathrm{ppm}, \mathrm{O}$-aromatic C $\left(\mathrm{C}_{\text {Aromatic }}-\mathrm{O}, \mathrm{N}\right)$ at $140-160 \mathrm{ppm}$ and carboxyl C $\left(\mathrm{C}_{\mathrm{COOH}}\right)$ at $160-190 \mathrm{ppm}$. The spectral average was obtained by descriptive statistics through analyzing the pure spectra data in Unscrambler 10.4 CAMO Software AS (Oslo, Norway).

\section{Determination of productive parameters}

At the time of harvest, approximately 125 days after planting, a total of 40 garlic plants were randomly selected in each trial group for analysis of the following parameters: plant height $(\mathrm{cm})$, internal and external quantities of cloves in bulb, fresh mass and dry mass of internal and external 

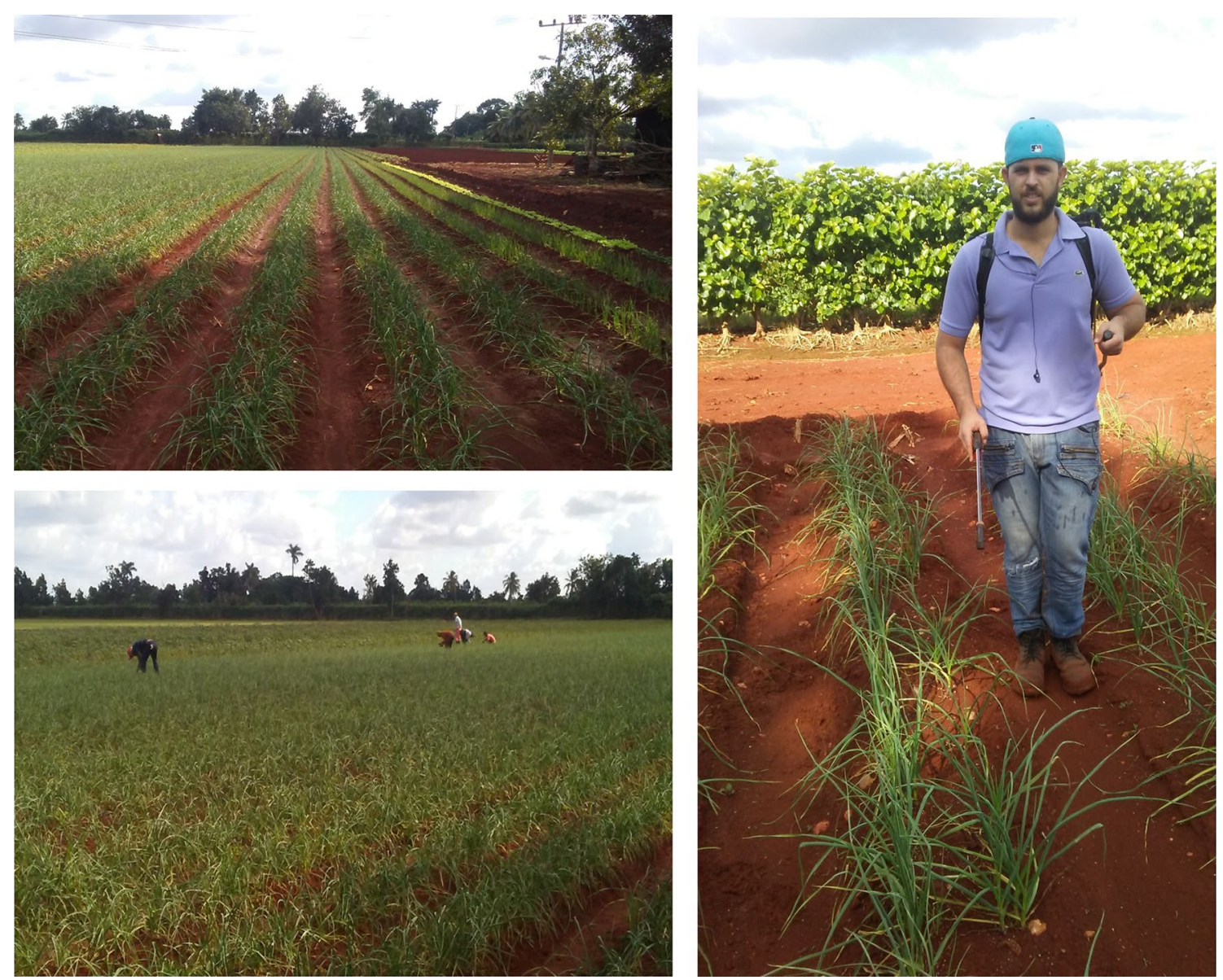

Fig. 1 Panoramic view of garlic crops in Cuba at the site where the experiment was carried out

bulbs $(\mathrm{g})$, diameter of garlic bulbs $(\mathrm{cm})$ and diameter of bulb $(\mathrm{cm})$.

\section{Determination of fruit quality parameters}

Quality parameters were evaluated considering the internal and external parts of the fruit. The evaluated external parameters were the caliber and the firmness. Following the methodology proposed by Burba (1993) that allows a classification level of 3,4 and 5, the caliber was determined by measuring the equatorial diameter of the bulb. The firmness of garlic bulbs, expressed as kilograms ( $\mathrm{kg} \mathrm{F}$ ), was determined using a CEMA-08 Digital Penetrometer, which measured the compressive force exerted until the garlic clove structure ruptured.

The internal parameters were measured by liquid extracts from peeled garlic cloves which were manually macerated and filtered through gauze tissue. Five different extracts constituting the five trial groups for each treatment were analyzed, for which the crude extract was diluted 10x.
Pungency was determined by the quantification of pyruvic acid content using spectrophotometry techniques and following the methodology of Benklebia (Benkeblia 2000a, b), Espinoza et al. (2010) and Grégrová et al. (2013). A volume of $2 \mathrm{~mL}$ diluted garlic extract was added to $2 \mathrm{~mL}$ of trichloroacetic acid (5\%) to deactivate the alliinase enzyme after which the mixture was kept at rest for $1 \mathrm{~h}$. Subsequently, the mixture was centrifuged for $1 \mathrm{~min}$ and $1 \mathrm{~mL}$ of supernatant was added to $1 \mathrm{~mL}$ of 2,4 dinitrophenylhydrazine dissolved in $\mathrm{HCl}(0.125 \mathrm{~g}$ in $1 \mathrm{~L}$ of $2 \mathrm{~mol} \mathrm{~L}^{-1} \mathrm{HCl}$ ). The mixture was incubated for $15 \mathrm{~min}$ at $37^{\circ} \mathrm{C}$, after which $5 \mathrm{~mL}$ of $\mathrm{NaOH}\left(0.1 \mathrm{~mol} \mathrm{~L}^{-1}\right)$ was added and then centrifuged for $10 \mathrm{~min}$. Pyruvic acid content was measured by obtaining absorbance at $490 \mathrm{~nm}$ and the standard curve generated with sodium pyruvate. The results were expressed as mmol (pyruvic acid)/mL (extract).

The ${ }^{\circ}$ Brix parameter (total soluble solids) of the garlic extract was determined using a hand refractometer (HR055). The electrical conductivity was determined using a Bentchop DDSJ-308A conductivity meter and the active 
acidity was determined using a pH meter PHSJ-3F. Total acids' content was determined by acid-base titration with $\mathrm{NaOH}\left(0.1 \mathrm{~mol} \mathrm{~L}^{-1}\right)$ and using phenolphthalein as an indicator, with results expressed as percentages of citric, malic, tartaric and pyruvic acid, following Domene and Segura (2014).

Total protein content, reducing carbohydrates and total carbohydrates were determined by spectrophotometric methods. Total protein content was quantified using the Biuret method, the standard curve was obtained with casein and absorbance was read at $540 \mathrm{~nm}$. Reducing carbohydrates were determined according to the method of Noelting and Bernfeld (1948) using 3.5 nitrosalicylic acid, while the methodology of Scott and Melvin (1953) was used to determine the total carbohydrate content; finally, the standard curve was constructed using the glucose values obtained in both methodologies.

\section{Statistical analysis of data}

Data analysis was performed by simple variance analysis (ANOVA) and means of comparison were performed using a Tukey test at a 95\% confidence level using Statgraphic program v 5.1 software. Principal component analysis was performed loading the averages organized in a $5 \times 24$ matrix using the Statgraphic Software v 5.1.

\section{Results and discussion}

\section{Structural characteristics of HS in the HEVC}

The ${ }^{13} \mathrm{C}$ NMR CP/MAS spectroscopy revealed the main types of carbon as well as the humic structures present in the HEVC; the spectrum is shown in Fig. 2. The peaks located in the spectrum between 0 and $45 \mathrm{ppm}(21.64,26.98$ and $34.42 \mathrm{ppm})$ indicate the presence of $-\mathrm{CH}_{3}$ and $-\mathrm{CH}_{2}\left(\mathrm{RC}=\mathrm{O} *-\mathrm{CH}_{3}\right)$, corresponding to carbohydrate structures and polypeptide chains. The region between 45 and $60 \mathrm{ppm}$ showed a peak at $52.48 \mathrm{ppm}$ belonging to methoxy carbons $\left(-\mathrm{OCH}_{3}\right)$ and $\mathrm{C} \alpha$, indicating the presence of polypeptide fragments $(\mathrm{R}-\mathrm{C}=\mathrm{O}-\mathrm{CH}-\mathrm{NH})$. The presence of cellulose, hemicellulose and lignin fragments in HEVC was confirmed by peaks at $69.45 \mathrm{ppm}$, belonging to carbinols $(-\mathrm{C}-\mathrm{OH})$ and $\mathrm{O}$-alkyl carbons, respectively. Other types of carbon that show the presence of carbohydrate and lignin fragments were confirmed by the presence of peaks approximately $101 \mathrm{ppm}(90-110 \mathrm{ppm})$, corresponding to anomeric carbons $\left(\mathrm{C}_{\mathrm{Alkyl}}-d i-\mathrm{O}\right)$ and $\mathrm{C}_{2}$ fragments of guaiacyl and syringyl. The structures responsible for aromaticity were identified by the presence of unsubstituted aromatic carbons marked at peaks approximately $129 \mathrm{ppm}$

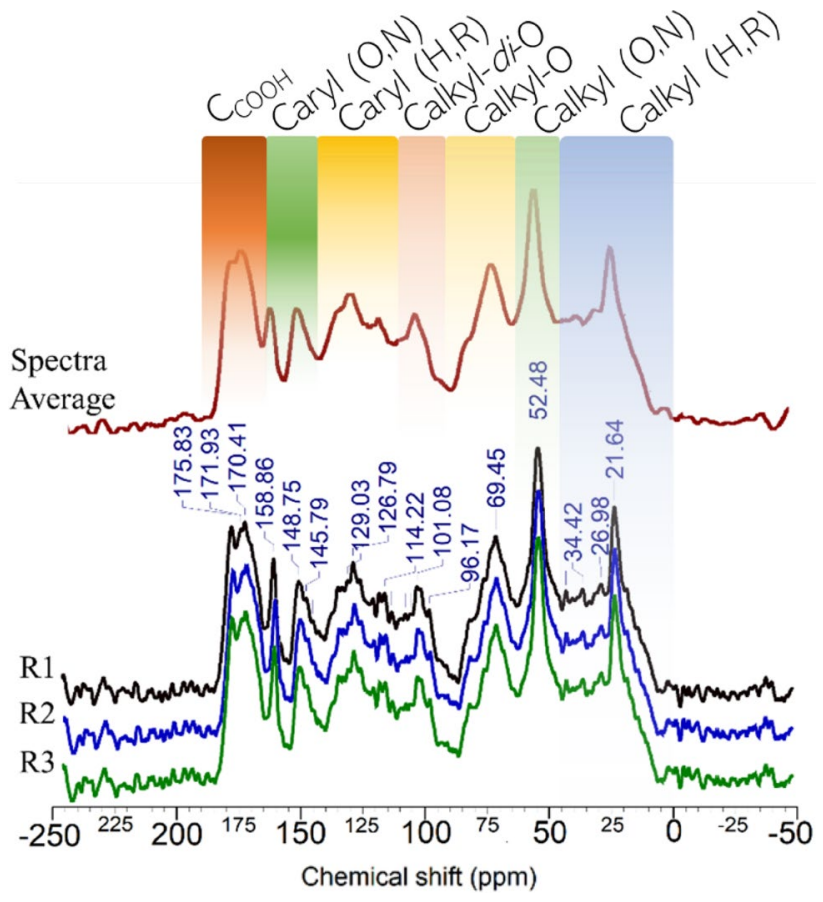

Fig. 2 The ${ }^{13} \mathrm{C}$ NMR CP/MAS spectra average (brown) of humic extract obtained from vermicompost. R1 (black), R2 (blue) and R3 (green) are spectra replicates collected from different extractions

(110-142 ppm); these signals correspond to $\mathrm{C} 1$ of guaiacyl and syringyl fragments. The functionalized aromatic structures $\left(\mathrm{C}_{\text {Arom }}-\mathrm{O}, \mathrm{N}\right)$ were identified from the presence of peaks approximately 145 and $148 \mathrm{ppm}(140-156 \mathrm{ppm})$. A major peak at $158 \mathrm{ppm}$ showed the presence of $\mathrm{C}_{\text {Aryl }}-\mathrm{O}-\mathrm{C}_{\text {Aryl }}$ structural-type fragments. However, the intense peak at $170 \mathrm{ppm}$ confirms the presence of carboxylic acid structures (Deshmukh et al. 2005; Johnson et al. 2005; Baldock and Preston 1992; Inbar et al. 1990).

The relative quantity of different humic structures in HEVC is shown in Table 1. Aliphatic structures in HS are predominant, indicating that $73.74 \%$ in HEVC is composed of peptides, carbohydrates and more lignin labile fragments. Aromatic structures responsible for greater recalcitrance in HEVC represent $26.26 \%$ of the total area in the spectra.

These structural characteristics present in HS contribute to guarantee HEVC bioactivity in plants. The potential bioactivity of HS in plants with these structural characteristics has been proven and reported in the scientific literature (Balmori et al. 2014; García et al. 2016a, b). Lignin structures and lignin-derived fragments responsible for the aromaticity property in HEVC have the ability to stimulate root emission in plants (Balmori et al. 2014). At the same time, it has been reported that both the presence of aliphatic and aromatic structures with low and high structural functionalization of the humic supramolecularity are responsible for 
Table 1 Relative distribution (total area \%) of chemical shift regions in ${ }^{13} \mathrm{C}$ CP MAS RMN spectrum

\begin{tabular}{|c|c|c|c|c|c|c|c|}
\hline \multicolumn{8}{|c|}{ Chemical shift $(\mathrm{cm})$} \\
\hline & $0-45$ & $45-60$ & $60-90$ & $90-110$ & $110-140$ & $140-160$ & $160-180$ \\
\hline & $\mathrm{C}-{ }_{\mathrm{C}-\mathrm{H}}$ & $\mathrm{C}-{ }_{\mathrm{C}-\mathrm{O}, \mathrm{N}}$ & $\mathrm{C}^{-}{ }_{\mathrm{C}-\mathrm{O}}$ & $\mathrm{C}-{ }_{\mathrm{O}-\mathrm{C}-\mathrm{O}}$ & $\mathrm{C}-{ }_{\mathrm{Ar}}$ & $\mathrm{C}-{ }_{\mathrm{Ar}-\mathrm{O}, \mathrm{N}}$ & $\mathrm{C}-{ }_{\mathrm{COOH}}$ \\
\hline HEVC & $21.21 \pm 1.23$ & $15.15 \pm 2.01$ & $14.14 \pm 1.87$ & $9.09 \pm 1.22$ & $16.16 \pm 1.29$ & $10.10 \pm 1.32$ & $14.14 \pm 1.45$ \\
\hline \multicolumn{8}{|c|}{ Aromaticity: $26.26 \%$} \\
\hline \multicolumn{8}{|c|}{ Alifaticity: $73.74 \%$} \\
\hline
\end{tabular}

root growth and development as well as for the increase in productive yield (García et al. 2016a, b; Berbara and García 2014; Hernández et al. 2015a, b).

\section{Foliar application effects of HEVC on garlic production and fruit quality}

\section{Effects on productive parameters}

Generally, the number of external cloves in a garlic bulb is greater than the number of internal cloves. Since internal cloves are smaller in size, both producers and consumers prefer bulbs with fewer internal cloves as the external cloves will then have greater size, thickness and height. Results obtained in this study showed that foliar application of HEVC significantly stimulated $(p<0.05)$ the main production parameters evaluated (Fig. 3). The results showed that foliar application of HEVC significantly stimulated the number of external cloves per bulb $(p<0.05)$ (Fig. 3a), fresh mass (Fig. 3b) and dry mass of external cloves per bulb (Fig. 3c) $(p<0.05)$ as well as fresh mass and dry mass of the bulb $(p<0.05)$ (Fig. 3d). For all evaluated parameters, the application of HEVC in dilution of 1:40 (v:v) ratio had the greatest stimulus when compared to control treatment.

While there are few studies reported in the literature showing the HS effects on garlic production indicators, our results show that the stimulus exerted by HEVC foliar application on the external mass of garlic cloves was larger than that reported by Izquierdo and Gómez (2012) for the criollo-9 variety $(1.35-1.41 \mathrm{~g})$ as well as that reported by
Fig. 3 Number of internal and external cloves (a), fresh weight of internal and external cloves (b) dry weight of internal and external cloves (c) fresh and dry weight of bulb from garlic plants treated with humic extract of vermicompost. (a...c) Different letters indicate significant differences between means for the Tukey test $(p<0.05)$
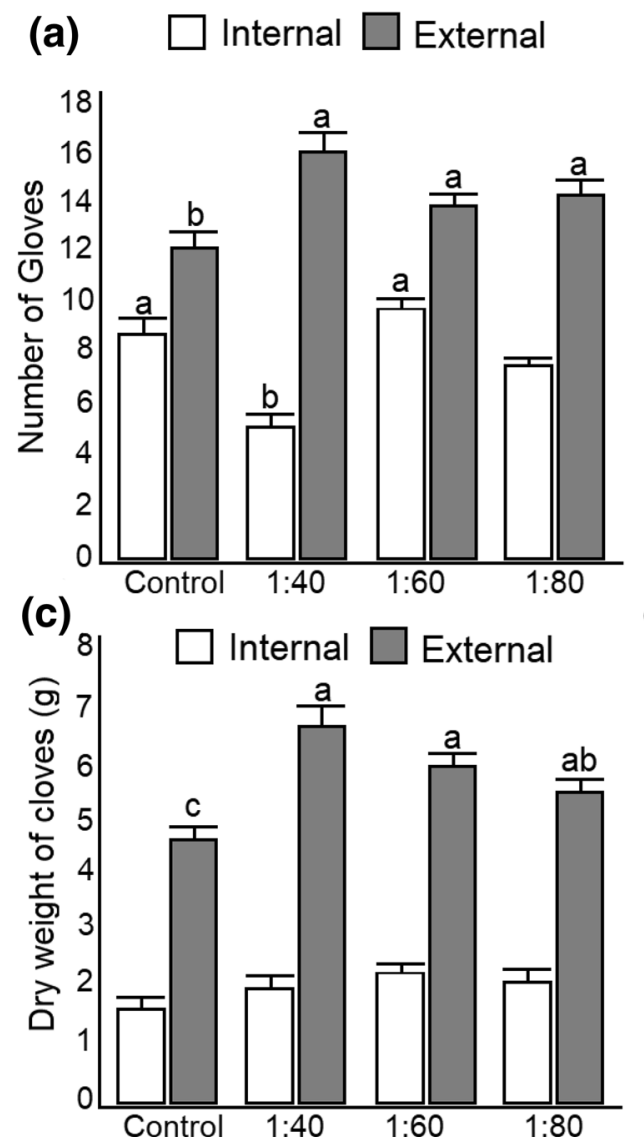

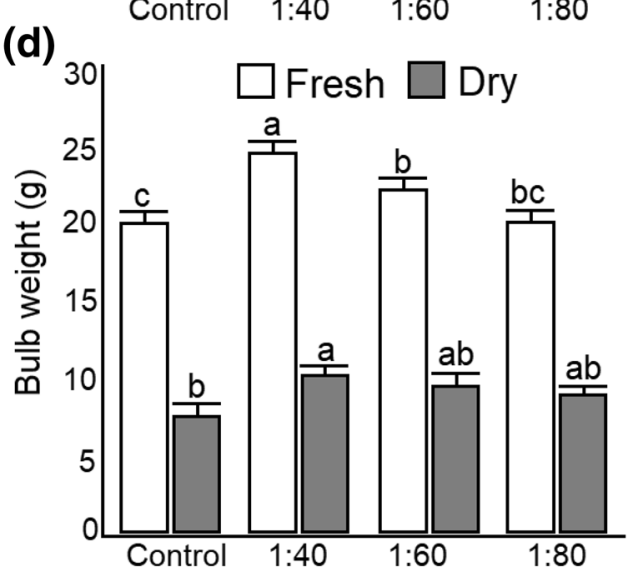


Grégrová et al. (2013). The mass of cloves is an especially important parameter because it is an indicator of the productive quality of the culture. Since the scientific literature does not establish quality ranges for this indicator, it is difficult to conclude the quality of production in this study; the values obtained here are smaller than those found by Izquierdo and Gómez (2012), yet they are higher than those reported by Pupo et al. (2016), which were collected in the planting seasons of 2011-2012 (18-23 g) and 2013-2014 (8-11 g).

In the specific case of Cuba where this study was carried out, it is important to establish quality criteria because there are reports of disease attacks (Thrips tobacco Lin.) with incidence rates of up to $25 \%$. Another issue is the typical tropical climate characteristics that presuppose specific edaphoclimatic conditions between harvests. Additionally, due to experimental barriers that do not allow comparisons of garlic quality indices, the few published studies on many occasions do not specify the application types or collection times, as well as the conditions under which the bulbs were analyzed in the postharvesting process (Izquierdo and Gómez 2012; Zaki et al. 2014).

\section{Effects on fruit quality parameters}

Quality of the garlic bulb can be classified by its caliber (classification by the equatorial diameter of bulb), pungency (determined from the content of gallic acid in the extract) and quantity of total soluble solids ( ${ }^{\circ} \mathrm{Brix}$ ) (Pardo et al. 2007). Firmness is also a quality parameter previously reported in the literature (Pardo et al. 2007, Grégrová et al. 2013).

Effects of HEVC foliar application on the bulb quality parameters and those obtained from the garlic extract are shown in Table 2. Results showed that all treatments applied to plants (1:40, 1:60 and 1:80 v:v) improve the fruit quality parameters when compared to the control treatment. Thus, for the parameters of bulb diameter, ${ }^{\circ} \mathrm{Brix}$ and $\mathrm{pH}$, the application effects were not significantly different between HEVC treatments $(p<0.05)$. The values of bulb diameter are within the range established in the literature for this same garlic variety (Izquierdo and Gómez 2012) and higher than those obtained by Pupo et al. (2016) when applying other biostimulants by foliar application, such as Ecomic ${ }^{\circledR}$ and FitoMas$\mathrm{E}^{\circledR}$, which both regulate plant growth and development.

Similar to results obtained for productive quality parameters, treatment of HEVC in dilution of 1:40 (v:v) rate improved the fruit quality parameters. Similar results were reported in biostimulant foliar application studies at similar HA concentrations, where the bulb diameter was stimulated in this study (Shafeek et al. 2015).

According to Burba (1993), a bulb diameter between 26 and $35 \mathrm{~mm}$ is classified as caliber 3, between 35 and $45 \mathrm{~mm}$
Table 2 Quality parameters of bulb and extract of garlic plants treated with humic extract from vermicompost

\begin{tabular}{lllll}
\hline Parameter & \multicolumn{4}{l}{ Treatments } \\
\cline { 2 - 4 } & Control & HEVC 1:40 & HEVC 1:60 & HEVC 1:80 \\
\hline Diameter (cm) & & & \\
Bulb & $3.520 \mathrm{c}$ & $3.922 \mathrm{a}$ & $3.832 \mathrm{ab}$ & $3.688 \mathrm{bc}$ \\
Neck of bulb & 0.83 & 0.93 & 0.89 & 0.89 \\
Caliber (\%) & & & & \\
3: 26-35 mm & 60 & - & 6.7 & 33.3 \\
4: $36-45 \mathrm{~mm}$ & 40 & 100 & 93.3 & 66.7 \\
${ }^{\circ}$ Brix & 15.33 & 14.66 & 15.66 & 14.33 \\
EC (mS cm $\left.{ }^{-1}\right)$ & $2.26 \mathrm{~b}$ & $2.44 \mathrm{a}$ & $2.45 \mathrm{a}$ & $2.48 \mathrm{a}$ \\
Active acidity pH & 6.58 & 6.62 & 6.55 & 6.64 \\
Titration acidity & & & & \\
$\quad$ (\%) & & & & \\
Citric acid & $0.66 \mathrm{~b}$ & $1.13 \mathrm{a}$ & $0.73 \mathrm{~b}$ & $0.85 \mathrm{ab}$ \\
Malic acid & $0.69 \mathrm{~b}$ & $1.18 \mathrm{a}$ & $0.75 \mathrm{~b}$ & $0.89 \mathrm{ab}$ \\
Tartaric acid & $0.77 \mathrm{~b}$ & $1.33 \mathrm{a}$ & $0.85 \mathrm{~b}$ & $0.99 \mathrm{~b}$ \\
Pyruvic acid & $0.90 \mathrm{~b}$ & $1.55 \mathrm{a}$ & $1.00 \mathrm{ab}$ & $1.17 \mathrm{ab}$ \\
\hline
\end{tabular}

(a...c) Different letters indicate significant differences between means for the Tukey test $(p<0.05)$

for caliber 4 and between 46 and $55 \mathrm{~mm}$ for caliber 5 . The garlic variety used in this study can produce bulbs of caliber 3 or 4, according to Izquierdo and Gómez (2012). While the present study did not produce bulbs of caliber 5 , caliber 4 bulbs were produced in plants where HEVC treatments were applied (Table 2).

Increased garlic bulb diameter due to HS application has been reported by several authors (Shafeek et al. 2015; Paradjikovic et al. 2014; Denre et al. 2014; Anjum et al. 2014, Zaki et al. 2014). Shafeek et al. (2015) reported the foliar application effect of HA on garlic cultivated under field conditions whereby plants treated with a higher concentration of HA produced larger bulbs. This result is in line with that found in this study, where the highest HS dose (HEVC 1:40) stimulated the largest diameter (Table 2). It is possible that HEVC has a positive effect on protein synthesis at the level of the RNA messenger (Trevisan et al. 2011), acting as a carrier of carbohydrates through membranes and thus favoring bulb growth. Since the bulb is the more important commercial attribute of these crops, increased bulb diameter due to the application of humic extract has an important commercial and economic implication.

The ${ }^{\circ}$ Brix values found in this study were shown to be slightly lower compared to those reported in the literature (17.2-21.3 ${ }^{\circ}$ Brix) (Izquierdo and Gómez 2012) and to other plant varieties with values between $25.1^{\circ}-29.4^{\circ}$ (Grégrová et al. 2013). This variability can be the response of plants to climatic conditions (humidity, temperature, precipitation, winds, atmospheric pressure, etc.). As ${ }^{\circ}$ Brix indicates the 
quantity of carbohydrates in fruit extracts and juices, our results indicate that there should be no changes in carbohydrate content by the use of HEVC. On the other hand, the electrical conductivity is indicative of the total content of salts, as well as the acidic and basic ionizable substances. In the present study, foliar application of HEVC significantly increased $(p<0.05)$ the electrical conductivity (EC) values in garlic extract (Table 2).

The $\mathrm{pH}$ values found in this work remained in the range of 6.55-6.64, similar to those reported by Pardo et al. (2007). These authors studied fourteen cultivars of garlic: five purple varieties (Moraluz, Morasol, Moratop, Mulvico and Planasa), seven of the white type (Basic, Corail, Christ, Garcua, Ramses, Supremo and Termídome) and two cultivars of the Chinese type (Chinese Planasa and Chinese Sprint). Other authors have reported lower values than those found in the present study for the varieties of Cincomesino, Barranquino precoce, Mapuri, Alfa suquia, Pata de perro and Barranquino tardio (Espinoza et al. 2010). The variation in $\mathrm{pH}$ values is highly dependent on garlic origin, soil type, sowing site, crop management and environmental factors.

Variations in the quantity of organic acids for garlic extract can influence the taste of food, color and conservation quality; the citric, malic and tartaric acids were found in the highest content in different fruits and vegetables (Domene and Segura 2014). In this study, acidity results are expressed as a percentage of pyruvic acid because when degraded, alliin, responsible for the odor and taste of garlic, produces this acid. Only the treatment of HEVC 1:40 was significantly $(p<0.05)$ higher than the control. In addition to organic acid content, organic compounds such as proteins and carbohydrates are related to the culinary, medicinal and insecticidal properties of garlic (Espinoza et al. 2010).

In the garlic trade, firmness of fruit is usually related to degree of maturation, and this relation which implies a lower fruit firmness will indicate a more advanced degree of maturity. For garlic crops, we do not find scientific references that establish quality parameters for this relationship; however, it is commercially accepted that a garlic bulb with greater firmness is more desirable for the market. Figure $4 \mathrm{a}$ shows the firmness of garlic bulb and clove in plants treated with different HEVC dilutions. For the bulb case, significant differences $(p<0.05)$ were found between treatments; the HEVC dilution of 1:40 (v:v) was significantly lower than the rest. Although these results may seem contradictory to the HEVC 1:40 treatment that produced a higher caliber and a low firmness, it is explained by the fact that larger bulbs
Fig. 4 Firmness of bulb and cloves of garlic plants treated with humic extract of vermicompot (a), pungency (b), protein content (c), total and reducing carbohydrates content (d) in garlic extract. (a...c) Different letters indicate significant differences between means for the Tukey test $(p<0.05)$

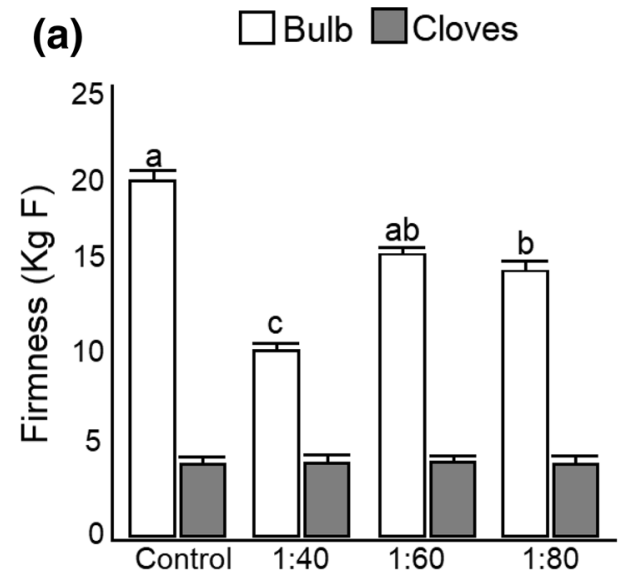

(b)

(c)

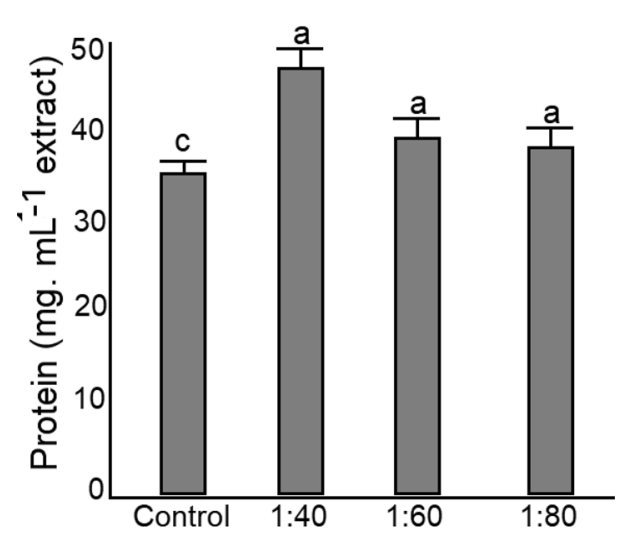

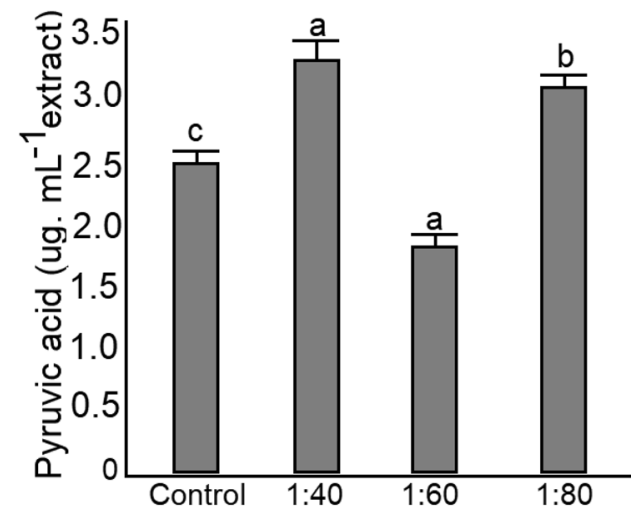

(d)

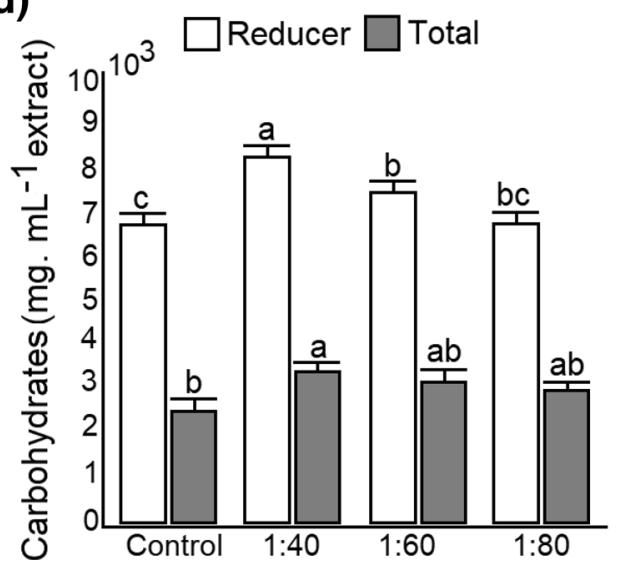


are less compacted, and garlic cloves can be more easily removed.

In garlic clove case, firmness was determined as the maximum force supported by cloves when penetrated until their rupture point. No significant differences were found between HEVC treatments, suggesting that HEVC dilutions via foliar application in garlic plants do not cause changes in this quality indicator. In the consulted literature, firmness is evaluated by penetration in cloves over bulbs; thus, the values above $5 \mathrm{~kg} \mathrm{~F}$ are reported (Pardo et al. 2007; Grégrová et al. 2013). The lower firmness found in garlic cloves compared to those reported in the literature may be result of studies carried out with other garlic varieties of higher caliber.

Pungency is another important indicator of fruit quality. When the bulb is damaged, the alliinase enzymatic action produces the conversion of the alliine $(+\mathrm{S}$-allyl cysteine sulfoxide) into allicin, pyruvic acid and ammonia. Thus, the pyruvic acid content (pungency) corresponds to the alliin concentration, which corresponds to the odor and taste of garlic (Espinoza et al. 2010). Figure 4b shows the results of pungency evaluated in the garlic extract of bulbs when different HEVC dilutions were applied to plants. The results show that foliar HEVC application promotes the stimulation of pyruvic acid production, with greater intensity in plants treated with the 1:40 (v:v) dilution, which is significantly different from the control treatment $(p<0.05)$ as well as other HEVC treatments. These results are in line with those obtained by Denre et al. (2014), wherein the authors studied the effect of different concentrations (100, 200, 300 and $400 \mathrm{ppm}$ ) of commercial HA on pungency of the Gangajali variety of garlic and reported a significant increase of this indicator in addition to an increase of HA concentration.

Although the results in this study showing higher concentration exerted the most intense effects, a relation between HS concentration and the improvement effect should not be generalized. The authors, such as Denre et al. (2014) studying the effect of different concentrations (200, 300 and $400 \mathrm{ppm}$ ) of garlic commercial humic acid on pungency (var. Gangajali), reported a greater increase at 300 ppm dosage.

The protein content in garlic cloves is shown in Fig. 4c. All HEVC treatments stimulated the increase of protein content. The HEVC treatment at a 1:40 (v:v) dilution increased the protein content with greater intensity, while more diluted treatments (1:60 and 1:80 v:v) stimulated higher protein synthesis compared to the control. In any case, all treatments showed significant differences when compared to control $(p<0.05)$.

Another important indicator of fruit quality is the carbohydrate content. Both garlic and onion plants use polysaccharides as reserve substances, and they are the most important for the garlic fruit as they determine bulb quality (Argüello et al. 2006). The results obtained for reducing carbohydrates and total carbohydrates in the garlic extract of bulbs when plants were treated with HEVC dilutions are shown in Fig. 4d. The application of HEVC did have significant effects $(p<0.05)$ on increasing content of reducing carbohydrate. The content of reducing carbohydrate was significantly higher in HEVC 1:40 v:v treatment when compared to control treatment.

Reducing carbohydrates have a potentially free carbonyl group in their structure, with all monosaccharides (glucose, fructose, mannose, etc.) and reducing disaccharides (maltose, cellobiose, etc.) included in this group of compounds. An effect of reducing carbohydrate content on leaves of corn plants treated with HS has been reported (Martínez et al. 2012; Canellas et al. 2013); while the glucose and fructose content decreased, the starch content increased concomitantly. Although no reduction in carbohydrate content was found in this study, a significant increase was found in total carbohydrates (Fig. 4d).

Carbohydrate content in fruits is dependent on the agronomic and environmental conditions during the growth stage of plants; however, it has been reported that polysaccharide content in garlic plants is stimulated when cultivated in soil mixed with vermicompost in the proportion of $1: 1 \mathrm{~m}: \mathrm{m}$ (Argüello et al. 2006). On the other hand, the content of fructans in six garlic cultivars was dependent on harvest time, as fruit collected within an intermediate period presented a high concentration of fructans compared to those collected in an earlier and later stage (Espinoza et al. 2010).

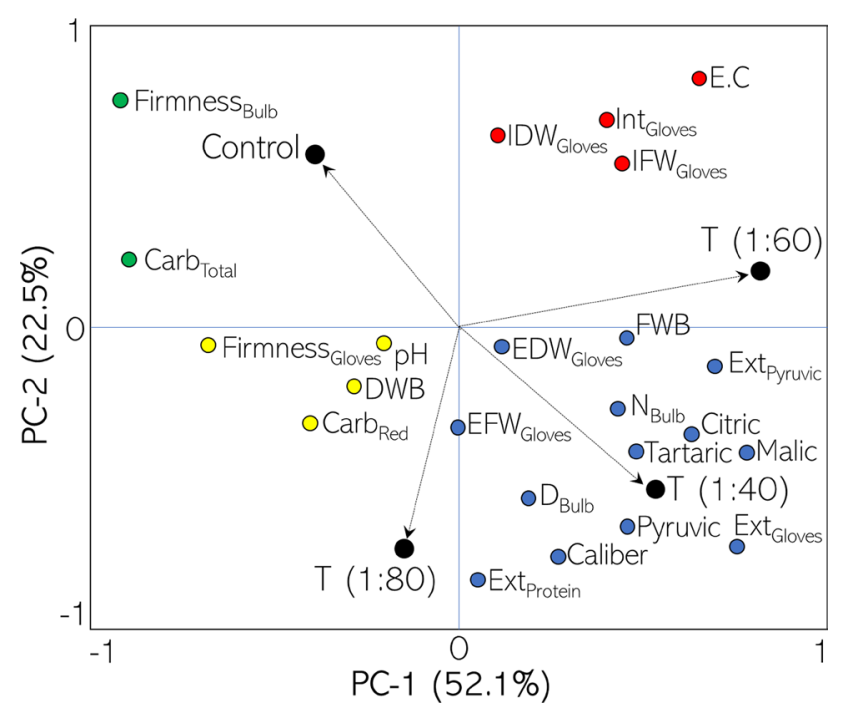

Fig. 5 Principal component analysis (PCA) performed from the parameters evaluated in all treatments with foliar application of HEVC in plants 


\section{Principal component analysis of the parameters evaluated}

Principal component analysis (PCA) related parameters evaluated with each applied HEVC treatment (Fig. 5). The PCA (explaining $74.6 \%$ of the total variance) showed that in PC-1 (explaining $52.1 \%$ of the variance), positive values grouped the internal quality variables of fruits with the 1:40 (v:v) treatment as well as variables such as fresh and dry masses of cloves and electrical conductivity with the 1:60 (v:v) treatment. Negative values of PC-1 grouped the control treatment with bulb firmness and total carbohydrates at the 1:80 v: v treatment with the parameters of cloves firmness, reducing carbohydrates, $\mathrm{pH}$ and dry mass of bulb.

These results reaffirm the previous discussion where the foliar application of more concentrated HEVC has a direct effect on the internal quality of fruit, but it does not seem to evoke a response in the amount of carbohydrates and firmness of fruits.

The effects exerted by HEVC used in this study have a high amount of HS in its composition. The potential of the humic extract obtained from vermicompost to improve internal fruit quality has been reported in the literature (Caro 2004; Hernández 2010; García et al. 2016a, b). Thus, HEVC can be an alternative for sustainable garlic production under small-scale conditions, as it could serve as a substitute for pest management and fertilization inputs (Pupo et al. 2016). Our results indicate that it is possible to include HEVC in a garlic production system, which could benefit biological productivity, agricultural productivity and fruit quality.

\section{Conclusions}

The HEVC applied to the garlic crop has a high amount of HS in its composition. Humic substances have a structure composed primarily of carbohydrates and peptides as well as modified lignin fragments. These structural features justify the positive stimulus effects on different forms of plant metabolism. The foliar application of HEVC improves the productive, commercial and internal quality parameters of fruits compared to the control treatment. The application of HEVC in the 1:40 (v:v) ratio was the most promising in terms of increases in fruit quality indices as well as promoting improvements in bulb caliber, garlic cloves and internal substance content in the fruit. HEVC can be a sustainable alternative introduced into the small-scale garlic technology package.

Funding This work was supported by the Fundação Carlos Chagas Filho de Amparo à Pesquisa do Estado do Rio de Janeiro (Grant no. sisFaperj: 2012028010), The Academy of Sciences for the Developing World (Grant no. Pós-doc), Fundação Carlos Chagas Filho de Amparo à Pesquisa do Estado do Rio de Janeiro and Conselho Nacional de
Desenvolvimento Científico e Tecnológico (Grant no. 306867/2018-4 PQ-2).

Open Access This article is distributed under the terms of the Creative Commons Attribution 4.0 International License (http://creativeco mmons.org/licenses/by/4.0/), which permits unrestricted use, distribution, and reproduction in any medium, provided you give appropriate credit to the original author(s) and the source, provide a link to the Creative Commons license, and indicate if changes were made.

\section{References}

Anjum K, Ahmed M, Baber JK, Alizai MA, Ahmed N, Tareen MH (2014) Response of garlic bulb yield to bio-stimulant (bio-cozyme) under calcareous soil. Life Sci Int J 8(1-4):3058-3062

Argüello JA, Ledesma A, Nuñez SB, Rodríguez CH, Díaz MCG (2006) Vermicompost effects on bulbing dynamics, nonstructural carbohydrate content, yield and quality of Rosado Paraguayo garlic bulbs. HortScience 41(3):589-592. https://doi. org/10.21273/HORTSCI.41.3.589

Badgley C, Moghtader J, Quintero E, Zakem E, Chappell MJ, AvilesVazquez K, Perfecto I (2007) Organic agriculture and the global food supply. Renew Agr Food Syst 22:86-108. https://doi. org/10.1017/S1742170507001640

Baldock J, Preston CM (1992) Assessing the extent of decomposition of natural organic materials using solid state ${ }^{13} \mathrm{C}$ NMR spectroscopy. Aust J Soil Res 35:1061-1083. https://doi.org/10.1071/ S97004

Balmori MD, Spaccini R, Aguiar NO, Novotny EH, Olivares FL, Canellas LP (2014) Molecular characteristics of humic acids isolated from vermicomposts and their relationship to bioactivity. J Agr Food Chem. 62:11412-11419. https://doi.org/10.1021/ jf504629c

Benkeblia N (2000a) Phenylalanine ammonia-lyase, peroxidase, pyruvic acid and total phenolics variations in onion bulbs during long-term storage. Lebensm-Wiss u-Technol 33:112-116. https://doi.org/10.1006/fstl.1999.0624

Benkeblia N (2000b) Phenylalanine ammonia-lyase, peroxidase, pyruvic acid and total phenolics variations in onion bulbs during long-term storage. LWT-Food Sci Technol 33:112-116. https://doi.org/10.1006/fstl.1999.0624

Berbara RLL, García AC (2014) Humic substances and plant defense metabolism. In: Parvaiz A, Wani MR (eds) Physiological mechanisms and adaptation strategies in plants under changing environment, vol 1. Springer Science + Business Media, New York, pp 297-319. https://doi.org/10.1007/978-1-4614-8591-9_11

Burba JL (1993) Producción de semilla de ajo. In: Manual de producción de semillas hortícolas. Ed. La Consulta. INTA-EEA La Consulta, Mendoza, Argentina

Canellas LP, Olivares FL (2014) Physiological responses to humic substances as plant growth promoter. Chem Biol Technol Agric 1-3:1-11. https://doi.org/10.1186/2196-5641-1-3

Canellas LP, Martínez Balmori D, Médici LO, Aguiar NO, Campostrini E, Rosa RC, Façanha A, Olivares FL (2013) A combination of humic substances and Herbaspirillum seropedicae inoculation enhances the growth of maize (Zea mays L.). Plant Soil 366:119-132. https://doi.org/10.1007/s11104-012-1382-5

Canellas LP, Olivares FL, Aguiar NO, Jones DL, Nebbioso A, Mazzei P, Piccolo A (2015) Humic and fulvic acids as biostimulants in horticulture. Sci Hortic 196:15-27. https://doi. org/10.1016/j.scienta.2015.09.013

Caro IG (2004) Caracterización de algunos parámetros químicofísico del humus líquido obtenido a partir de vermicompost 
de estiércol vacuno y su evaluación sobre algunos indicadores biológicos y productivos de dos cultivos. Master Dissertation, Agrarian University of Havana

Crowder DW, Northfield TD, Strand MR, Snyder WE (2010) Organic agriculture promotes evenness and natural pest control. Nature 466:109. https://doi.org/10.1038/nature09183

Denre M, Ghanti S, Sarkar K (2014) Effect of humic acid application on accumulation of mineral nutrition and pungency in garlic (Allium sativum L.). Int J Biotechnol Mol Biol Res 5:7-12. https ://doi.org/10.5897/ijbmbr2014.0186

Deshmukh AP, Simpson AJ, Hadad CM, Hatcher PG (2005) Insights into the structure of cutin and cutan from Agave americana leaf cuticle using HRMAS NMR spectroscopy. Org Geochem 36:1072-1085. https://doi.org/10.1016/j.orggeochem .2005 .02 .005

Domene MA, Segura M (2014) Parámetros de calidad Interna de hortalizas y frutas en la industria agroalimentaria. Negocios Agroalimentario Cooper Cajamar Fichas Transf 005:1-18

Espinoza FWC, Ríos EMR, Elías CCAP (2010) Determinación de fenoles totales, fructanos y pungencia en seis cultivares de ajos (Allium sativum L.) en el Perú. Rev Soc Quím Perú 76(1):101-109

García AC, Santos LA, Izquierdo FG, Sperandio MVL, Castro RN, Berbara RLL (2012) Vermicompost humic acids as an ecological pathway to protect rice plant against oxidative stress. Ecol Eng 47:203-208. https://doi.org/10.1016/j.ecoleng.2012.06.011

García AC, Izquierdo FG, González OLH, De Armas MMD, López RH, Rebato SM, Balmori DM, Berbara RLL (2013) Biotechnology of humified materials obtained from vermicomposts for sustainable agroecological purposes. Afr J Biotechnol 7:625-634. https://doi.org/10.5897/AJBX12.014

García AC, Izquierdo FG, Berbara RLL (2014) Effects of humic materials on plant metabolism and agricultural productivity. In: Emerging technologies and Management of crop stress tolerance (pp. 449-466). Academic Press. https://doi.org/10.1016/b978-012-800876-8.00018-7

García AC, Souza LGA, Pereira MG, Castro RN, García-Mina JM, Zonta E, Lisboa FJG, Berbara RLL (2016a) Structure-propertyfunction relationship in humic substances to explain the biological activity in plants. Nature Sci Rep. https://doi.org/10.1038/srep2 0798

García AC, Pimentel QJ, Balmori MD, Huelva LR, Guridi IF (2016b) Efeitos no cultivo do milho de um extrato líquido humificado residual, obtido a partir de vermicomposto. Rev Cie Téc Agr 25:38-43

Garcia-Mina JM, Antolin MC, Sanchez-Diaz M (2004) Metal-humic complexes and plant micronutrient uptake: a study based on different plant species cultivated in diverse soil types. Plant Soil 258:57-68. https://doi.org/10.1023/b:plso.0000016509.56780.40

Grégrová A, Č́ížková H, Bulantová I, Rajchl A, Voldřich M (2013) Characteristics of garlic of the czech origin. Czech J Food Sci 31:581-588. https://doi.org/10.17221/539/2012-cjfs

Hernández OL (2010) Modificaciones al proceso de obtención de sustancias húmicas a partir de vermicompost: efectos biológicos. Master Dissertation, Agrarian University of Havana

Hernández OL, Calderín A, Huelva R, Martínez-Balmori D, Guridi F, Aguiar NO, Olivares FL, Canellas LP (2015a) Humic substances from vermicompost enhance urban lettuce production. Agron Sustain Dev 35:225-232. https://doi.org/10.1007/s13593-014-0221-x

Hernández A, Pérez JM, Bosch D, Castro N (2015b) Clasificación de los Suelos de Cuba. Instituto Nacional de Ciencias Agrícolas e Instituto de Suelos de Cuba. Mayabeque, Cuba, p 64

Inbar Y, Chen Y, Hadar Y (1990) Humic substances formed during the composting of organic matter. Soil Sci Soc Am J 54:1316-1323. https://doi.org/10.2136/sssaj1990.03615995005400050019x

Izquierdo HO, Gómez OC (2012) Informe de variedades 'Criollo-9', un cultivar de ajo resistente a las enfermedades fitopatógenas y elevado potencial de rendimiento. Cult Trop 33(2):68 (ISSN impreso: 0258-5936. ISSN digital: 1819-4087)

Johnson CE, Smernik RJ, Siccama TG, Kiemle DK, Xu Z, Vogt DJ (2005) Using ${ }^{13 C}$ nuclear magnetic resonance spectroscopy for the study of northern hardwood tissues. Can J For Res 35:1821-1831. https://doi.org/10.1139/x05-122

Martínez D, Huelva R, Portuondo L, Guridi F (2012) Evaluación del efecto protector de las Sustancias Húmicas Líquidas en plantas de maíz cultivar P-2928 en condiciones de salinidad. Centro Agr 39:29-32 (ISSN papel: 0253-5785. ISSN on line: 2072-2001)

Mora V, Bacaicoa E, Zamarreno AM, Aguirre E, Garnica M, Fuentes M, García-Mina JM (2010) Action of humic acid on promotion of cucumber shoot growth involves nitrate-related changes associated with the root-to-shoot distribution of cytokinins, polyamines and mineral nutrients. J Plant Physiol 167:633-642. https://doi. org/10.1016/j.jplph.2009.11.018

Noelting G, Bernfeld P (1948) Sur les enzimes amylolytiques. III. La \& \#x03B1;-amilase: dosage d'activité et controle de làbsence d' -amilase. Helv Chim Acta 31:286-290. https://doi.org/10.1002/ hlca. 19480310637

Paradjikovic N, Tkalec M, Zeljkovic S, Vinkovic T (2014) Biostimulant application in transplants production of Allium Sativum L. and Wild Roses (Rosa Canina L.). In: Fifth International Scientific Agricultural Symposium “Agrosym 2014”, pp 694-699. https:// doi.org/10.7251/agsy1404694p

Pardo JE, Escribano J, Gómez R, Alvarruiz A (2007) Physical-chemical and sensory quality evaluation of garlic cultivars. J Food Qual 30:609-622. https://doi.org/10.1111/j.1745-4557.2007.00146.x

Pupo CF, Ramírez GG, Carmenate OF, Peña LM, Pérez VL, Rodríguez E (2016) Respuesta del cultivo del ajo (Allium sativum L.) a la aplicación de dos bioproductos en las condiciones edafoclimáticas del centro este de la provincia Las Tunas, Cuba. Culti Trop 37:57-66. https://doi.org/10.13140/RG.2.2.24385.97125

Reganold JP, Wachter JM (2016) Organic agriculture in the twentyfirst century. Nat plants 2(2):15221. https://doi.org/10.1038/nplan ts. 2015.221

Scott TA Jr, Melvin EH (1953) Determination of dextran with anthrone. Anal Chem 25:1656-1666. https://doi.org/10.1021/ac60083a023

Shafeek MR, Ali AH, Mahmoud AR, Hafez MM, Rizk FA (2015) Improving growth and productivity of garlic plants (Allium sativum L.) as affected by the addition of organic manure and humic acid levels in sandy soil conditions. Int J Curr Microbiol App Sci 4:644-656 (ISSN: 2319-7706)

Trevisan S, Botton A, Vaccaro S, Vezzaroa A, Quaggiotti S, Nardi S (2011) Humic substances affect Arabidopsis physiology by altering the expression of genes involved in primary metabolism, growth and development. Environ Exp Bot 74:45-55. https://doi. org/10.1016/j.envexpbot.2011.04.017

Uzo JO, Currah L (2018) Cultural systems and agronomic practices in tropical climates. In: Rabinowitch HD (eds) Onions and allied crops. Agronomy biotic interactions, vol 2. CRC press, Boca Raton, p 14. https://doi.org/10.1201/9781351075152

Warman PR, AngLopez MJ (2010) Vermicompost derived from different feedstocks as a plant growth medium. Bioresource Technol 101:4479-4483. https://doi.org/10.1016/j.biortech.2010.01.098

Zaki HEM, Toney HSH, Abd Elraouf RM (2014) Response of two garlic cultivars (Allium sativum L.) to inorganic and organic fertilization. Nature Sci 12:52-60 (ISSN: 1545-0740)

Publisher's Note Springer Nature remains neutral with regard to jurisdictional claims in published maps and institutional affiliations. 